\title{
Retraction Note to: Stem Cell Mediated Tooth Regeneration: New Vistas in Dentistry
}

\author{
M. Sujesh • V. Rangarajan • C. Ravi Kumar • \\ G. Sunil Kumar
}

Published online: 12 July 2013

(C) Indian Prosthodontic Society 2013

Retraction Note to: J Indian Prosthodont Soc (Jan-Mar 2012) 12(1):1-7

DOI 10.1007/s13191-011-0110-9

This article has been retracted by the Editor-in-Chief as it was a duplication of the article "STEM CELLS FOR TOOTH ENGINEERING" by G. Bluteau et al. which has been published in the journal "European Cells and Materials" (2008) volume 16 pages $1-9$.

The online version of the original article can be found under doi:10.1007/s13191-011-0110-9.

M. Sujesh $(\varangle) \cdot$ C. Ravi Kumar · G. Sunil Kumar

Department of Prosthodontics, Mamata Dental College

and Hospitals, Giriprasad Nagar, Khammam,

Andhra Pradesh 507002, India

e-mail: drmsujesh@gmail.com

V. Rangarajan

Department of Prosthodontics, Vels Dental College

and Hospitals, Chennai, Tamil Nadu, India 